\title{
SCREENING OF PLANT-DERIVED EXTRACTS AGAINST DNASE PRODUCTION OF Staphylococcus Aureus 1582
}

\author{
Krystel Grace V. Padilla ${ }^{1 *}$ \\ ${ }^{1 *}$ College of Arts and Sciences, Nueva Ecija University of Science and Technology, \\ Cabanatuan City, Nueva Ecija, 3100, Philippines; \\ *Corresponding Author Krystel Grace V. Padilla, e-mail: krystelpadilla27@gmail.com;
}

Received November 2021; Accepted December 2021; Published January 2022;

DOI: https://doi.org/10.31407/ijees12.133

\begin{abstract}
The pursuit for the inhibition of quorum sensing (QS) systems with the use of plants is a developing approach intended at developing natural products to reduce or eradicate the making of virulence factors by pathogenic and multidrug-resistant bacteria. QSI proposed an innovative perception on the application of pure or natural compounds as beneficial agents with the benefit of dropping risks of resistance growth. The ethnobotanicals from the Igorot community of Barangay Imugan, Sta. Fe, Nueva Vizcaya Philippines, was tested for its quorum sensing inhibition activity against Staphylococcus aureus PNCM 1582 through the DNase assay after the antibacterial testing. These were Bidens pilosa, Cestrum nocturnum, Sarcandra glabra, Pittosporum pentandrum, Oreocnide trinervis, Derris elliptica, Alstonia scholaris, Ageratina adenophora, Ayapana triplinervis, and Lipang Daga (no known scientific name). Extraction was done using $95 \%$ n-hexane. All ethnobotanicals extract did not show antibacterial activity and no inhibition of DNase production. However, all plant extracts have the potential to combat other virulence factors produced by some bacteria, which can possibly combat antimicrobial resistance. Further screenings on other virulence assays are recommended.
\end{abstract}

Keywords: DNase, quorum sensing inhibition, virulence, Staphylococcus aureus 